\title{
MENUMBUHKAN KETERAMPILAN BERPIKIR TINGKAT TINGGI MELALUI BUKU TEMATIK KELAS RENDAH DI SEKOLAH DASAR / MADRASAH IBTIDAIYAH
}

\author{
Andi Prastowo \\ Universitas Islam Negeri Sunan Kalijaga Yogyakarta \\ Email: andi.prastowo@uin-suka.ac.id
}

Naskah diterima : 10 Agustus 2019, direvisi : 5 September 2019, disetujui : 10 September 2019

\begin{abstract}
The quality of primary education in Indonesia in the last two decades has not changed much. One of the reasons for this condition is that learning at the elementary school/ madrasah level of madrasah has not yet developed high-level thinking skills. Therefore, starting in 2013, the government changed the primary education curriculum by presenting the 2013 curriculum. One of the substantial changes is that subjects are presented thematically for elementary schools/ madrasah ibtidaiyah. The curriculum change also gave birth to thematic textbooks, no longer subject-based textbooks. This study aims to describe what high-level thinking skills are developed through thematic books for students and how to design learning to grow these thinking skills in thematic books for teachers. This research applies a qualitative approach to the design of library studies. The primary source of this study is a thematic book for students and teachers in low grades, grades 1-3. Analysis of the data of this research through three stages, namely data condensation, data display, and drawing conclusions or verification. This study found that students' thematic books present higher-order thinking skills at the C4-C6 level referring to the revised Bloom's taxonomy. Student thematic books also present material to foster the ability to reason, think critically / creatively, and reasoning abilities. Meanwhile, the design of learning in the teacher's thematic books to promote higher-order thinking skills uses a scientific learning approach and is student-centred.
\end{abstract}

Keywords: Skills, Thinking, High, Books, Thematic, Low.

Pengutipan: Andi Prastowo. (2019). Menumbubkean Keterampilan Berpikir Tingkat Tinggi Melalui Buku Tematik Kelas Rendah di Sekolah Dasar / Madrasah Ibtidaiyah. JMIE: Journal of Madrasah Ibtidaiyah Education,3(2), 2019, 100-117. jmie.v3i2.126.

Permalink/DOI: http://dx.doi.org/10.32934/jmie.v3i2.126 


\section{INTRODUCTION}

Pendidikan dasar di Indonesia selama dua decade terakhir tidak mengalami perubahan yang berarti, terutama jika dilihat dari mutu luaran ataupun dampaknya. Laporan Programme for International Student Assessment (PISA) tahun 2015 menyajikan capaian skor peserta didik Indonesia di peringkat 62 dari 70 negara yang dievaluasi (OECD, 2018). Sejak keikutsertaannya dalam survei PISA tahun 2000 (OECD Indonesia, 2016) sampai sekarang, Indonesia bahkan hampir selalu menempati peringkat 10 besar terendah dari semua negara yang terlibat. Laporan PISA juga mengungkapkan fakta bahwa lebih dari 75\% peserta didik di Indonesia memiliki nilai di bawah tingkat 2 dalam Matematika (OECD Indonesia, 2016). Ini artinya masih banyak peserta didik di Indonesia yang memiliki kemampuan di bawah tingkat kemahiran dasar yang diperlukan untuk partisipasi penuh dalam masyarakat. Hal yang sama juga terjadi dalam Trends in Mathematic and Science Study (TIMSS) (Tim Redaktur Bernas, 2017). Menurut laporan TIMSS tahun 2015, skor yang dicapai peserta didik kelas 4 dari Indonesia untuk bidang Matematika hanya 397 (TIMSS, 2015). Ini artinya peserta didik Indonesia berada pada tingkatan kemampuan matematika paling bawah, yaitu "Low" (rendah). Makna peringkat "Low" (rendah) adalah peserta didik memiliki pengetahuan matematika dasar (Mullis, Martin, \& Loveless, 2016). Ini juga berarti kemampuan peserta didik Indonesia masih di bawah level dapat menerapkan pengetahuan matematika dasar dalam situasi sederhana. Kemampuan peserta didik Indonesia dalam bidang Sains juga tidak jauh berbeda dengan capaian mereka dalam bidang Matematika. Rekapitulasi peringkat PISA dan TIMSS Indonesia dari keikutsertaan pertama hingga sekarang disajikan pada Tabel 1.

Tabel 1: Peringkat Peserta Didik Indonesia dalam PISA dan TIMSS

\begin{tabular}{cccccccc}
\hline \multicolumn{2}{c}{ PISA } & \multicolumn{5}{c}{ TIMSS } \\
\hline Tahun & $\begin{array}{c}\text { Peringkat } \\
\text { dari atas }\end{array}$ & $\begin{array}{c}\text { Peringkat } \\
\text { dari bawah }\end{array}$ & $\begin{array}{c}\text { Jumlah } \\
\text { Negara }\end{array}$ & Tahun & $\begin{array}{c}\text { Peringkat } \\
\text { dari atas }\end{array}$ & $\begin{array}{c}\text { Peringkat } \\
\text { dari bawah }\end{array}$ & $\begin{array}{c}\text { Jumlah } \\
\text { Negara }\end{array}$ \\
\hline 2000 & 38 & 3 & 41 & 1999 & 32 & 6 & 38 \\
2003 & 38 & 2 & 40 & 2003 & 37 & 9 & 46 \\
2006 & 50 & 7 & 57 & 2007 & 35 & 14 & 49 \\
2009 & 60 & 5 & 65 & 2011 & 40 & 2 & 42 \\
2012 & 71 & 2 & 72 & 2015 & 39 & 6 & 44 \\
2015 & 64 & 8 & 72 & - & - & & - \\
\hline
\end{tabular}

Sumber: (Nugroho, 2018) 
Rendahnya kualitas pendidikan dasar di Indonesia tersebut merupakan salah satu dampak dari proses dan praksis pendidikan dasar selama ini. Tjala mengidentifikasi sejumlah kelemahan pendidikan dasar yang menyebabkan peringkat Indonesia dalam berbagai survei dan penilaian lembaga internasional tersebut masih rendah, yaitu: pertama, kelemahan dalam bidang Matematika yaitu proses pembelajarannya selama ini belum menciptakan kebiasaan membaca sambil berpikir dan bekerja sampai dengan memahami informasi esensial dan strategis (Tjalla, 2010). Pembelajaran matematika belum menitikberatkan pada kegiatan penalaran, namun justru aktivitas mekanistik semata. Kedua, kelemahan dalam bidang Sains meliputi: tidak mampu menunjukkan beberapa konsep yang abstrak dan kompleks dalam biologi, kimia, fisika dan ilmu bumi; tidak mampu memahami kompleksitas makhluk hidup dan hubungan mereka dengan lingkungannya; tidak mampu memahami sifat magnet, suara, dan cahaya serta perubahannya; tidak mampu menerapkan pengetahuannya tentang tata surya, ciri-ciri bumi dan prosesnya, serta menerapkan pengetahuannya pada masalah lingkungan; tidak mampu memahami dasardasar penyelidikan ilmiah dan menerapkan prinsip-prinsip fisika untuk memacahkan masalah kuantitatif; dan tidak mampu memberikan penjelasan secara tertulis untuk menyampaikan pengetahuan ilmiah (Tjalla, 2010). Penjelasan tersebut mengandung arti bahwa kelemahan mendasar peserta didik di Indonesia disebabkan karena rendahnya kebiasaan dan kemampuan menalar, ketidak mampuan beragumentasi, lemahnya berpikir kritis dan kreatif, tidak dimilikinya kemampuan penyelidikan ilmiah sekaligus keterampilan menulis karya ilmiah. Dengan kata lain, kemampuan berpikir tingkat tinggi masih belum menjadi prioritas dan penekanan dalam proses pembelajaran pada pendidikan dasar, terutama jenjang Sekolah Dasar atau pun Madrasah Ibtidaiyah.

Keterampilan berpikir tingkat tinggi menurut Resnick dalam Ariyana, dkk., adalah“...proses berpikir kompleks dalam menguraikan materi, membuat kesimpulan, membangun representasi, menganalisis, dan membangun hubungan dengan meliatkan aktivitas mental yang paling dasar" (Ariyana, Pudjiastuti, \& Bestary, 2018). Bloom membagi keterampilan berpikir menjadi dua klasifikasi yaitu keterampilan berpikir tingkat rendah meliputi: mengingat (remembering), memahami (understanding), dan menerapkan (applying); sedangkan keterampilan berpikir tingkat tinggi meliputi: menganalisis (analysing), mengevaluasi (evaluating), dan mencipta (creating) (Ariyana et al., 2018). Ini juga berarti keterampilan berpikir tingkat tinggi meliputi 3 dimensi proses berpikir yaitu: menganalisis (C4), mengevaluasi (C5), dan mencipta (C6) yang mencakup 3 dimensi pengetahuan yakni konseptual, procedural, dan metakognitif. Di samping itu, keterampilan berpikir tingkat tinggi meliputi 3 aspek yaitu: keterampilan transfer of knowledge, berpikir kritis dan kreatif, dan pemecahan masalah (problem solving) (Ariyana et al., 2018). Sajidan dan Afandi menambahkan bahwa berpikir tingkat tinggi ( Higher Order Thinking Skills/HOTs) merupakan keterampilan interaksional antara factor genetic dan lingkungan belajar sehingga HOTs cenderung bersifat dinamis dan berkembang secara eksponensial sejalan dengan pengalaman dan kematangan usia (Sajidan \& Afandi, 2018). Ini 
juga berarti bahwa proses menumbuhkan HOTs bagi peserta didik membutuhkan waktu yang tidak singkat, bahkan perlu pemberdayaan berkelanjutan seiring dengan perkembangam peserta didik dan jenjang pendidikan (TK sampai dengan PT).

Pemerintah Indonesia melalui Kementerian Pendidikan dan Kebudayaan pada tahun 2013 mengambil kebijakan transformatif untuk memperbaiki salah satunya yaitu kondisi rendahnya mutu pendidikan dasar dan menengah, yaitu melakukan perubahan kurikulum 2006 dengan kurikulum 2013 (K-13) (Anwar, 2014). Dalam konteks pendidikan dasar jenjang Sekolah Dasar / Madrasah Ibtidaiyah, kurikulum baru ini berimplikasi kepada penekanan pendekatan saintifik dan model pembelajaran tematik integratif dalam proses pembelajaran (Sendari, 2019). Lahir pula buku tematik untuk guru dan siswa sebagai bahan ajar utama dalam pembelajaran tematik di jenjang SD/MI. Keberadaan buku ajar tematik ini untuk proses pembelajaran di jenjang SD/ MI diharapkan dapat menyediakan materi yang menumbuhkan keterampilan berpikir tingkat tinggi pada peserta didik (Anwar, 2014) seperti melalui pembelajaran berbasis penguatan penalaran, bukan lagi hanya pada keterampilan berpikir tingkat rendah.

Studi mengenai keterampilan berpikir tingkat tinggi telah banyak dilakukan. Tema-tema studi berkaitan HOTS yang selama ini telah muncul di antaranya yaitu: proses berpikir tingkat tinggi dalam perspektif neurologis (Sajidan \& Afandi, 2018); pendekatan pembelajaran untuk menumbuhkan HOTS (Sahoo \& Mohammed, 2018); model-model pembelajaran untuk membelajarkan HOTS (Wahid \& Karimah, 2018); pengembangan bahan ajar untuk menumbuhkan HOTS (Pratiwi, Hidayah, \& Martiana, 2017; Yuliati, 2013); hubungan HOTS dan level kecerdasan dengan literasi sains (Yuriza, Adisyahputra, \& Sigit, 2018); HOTS sebagai strategi kontra radikalisme santri (Ardiansyah, 2018); instrument penilaian HOTS (Hamdu, Lestari, \& Nurlaila, 2016); dan analisis tugas-tugas dalam TIMSS yang membutuhkan HOTS (Tajudin \& Chinnappan, 2016). Dari berbagai tema tersebut, tema mengenai analisis konten buku ajar dan desain pembelajaran tematik yang menumbuhkan HOTS masih kurang mendapatkan perhatian. Padahal keberadaan bahan ajar dan desain pembelajaran yang relevan dengan HOTS sangat penting kedudukannya dalam menentukan keberhasilan pembelajaran unyuk menumbuhkan keterampilan berpikir tingkat tinggi.

Berangkat dari kondisi di atas, penelitian ini memiliki asumsi bahwa upaya pemerintah Indonesia menerapkan K-13 untuk SD/MI yang berimplikasi pada penerapan pendekatan pembelajaran saintifik dan model pembelajaran tematik, kemudian secara simultan disertai dengan kehadiran buku tematik siswa dan guru semestinya diikuti dengan tumbuhnya keterampilan berpikir tingkat tinggi pada peserta didik. Namun, laporan PISA dan TIMSS pada tahun 2015 justru menunjukkan belum ada perubahan berarti pada kemampuan peserta didik di SD/MI di Indonesia. Pertanyaan yang menjadi fokus dalam penelitian ini yaitu: pertama, apa saja keterampilan berpikir tingkat tinggi yang ditumbuhkan melalui buku tematik kelas rendah? 
Kedua, bagaimana desain pembelajaran untuk menumbuhkan keterampilan berpikir tersebut dalam buku tematik kelas rendah?

\section{METODE PENELITIAN}

Penelitian ini menggunakan pendekatan kualitatif dengan jenis riset studi pustaka. Oleh karena itu, penelitian ini disebut pula penelitian interpretatif, peneliti menjadi instrument kunci, dan penelitian ini juga menggunakan analisis data secara induktif (Creswell, 2009). Dalam studi ini, sumber data utama yang dianalisis adalah buku tematik cetakan tahun 2017 untuk guru (16 buku) dan untuk peserta didik (16 buah) yang berada di kelas rendah, yaitu kelas 1-3, seperti disajikan pada Tabel 2.

Tabel 2: Sumber Data Primer: Buku Tematik bagi Peserta Didik dan Guru di Kelas Rendah

\begin{tabular}{|c|c|c|c|c|c|c|c|}
\hline \multirow{2}{*}{ No. } & \multirow{2}{*}{ Tema } & \multicolumn{2}{|c|}{ Kelas 1} & \multicolumn{2}{|c|}{ Kelas 2} & \multicolumn{2}{|c|}{ Kelas 3} \\
\hline & & BG & BS & BG & BS & BG & BS \\
\hline 1 & Diriku & 1 & 1 & & & & \\
\hline 2 & Kegemaranku & 1 & 1 & & & & \\
\hline 3 & Kegiatanku & 1 & 1 & & & & \\
\hline 4 & Keluargaku & 1 & 1 & & & & \\
\hline 5 & Pengalamanku & 1 & 1 & & & & \\
\hline 6 & Lingkungan bersih, sehat, dan asri & 1 & 1 & & & & \\
\hline 7 & Benda, hewan, dan tanaman di sekitarku & 1 & 1 & & & & \\
\hline 8 & Peristiwa alam & 1 & 1 & & & & \\
\hline 9 & Hidup rukun & & & 1 & 1 & & \\
\hline 10 & Bermain di lingkunganku & & & 1 & 1 & & \\
\hline 11 & Tugasku sehariTugasku sehari -hari & & & 1 & 1 & & \\
\hline 12 & Aku dan sekolahku & & & 1 & 1 & & \\
\hline 13 & Hidup bersih dan sehat & & & 1 & 1 & & \\
\hline 14 & Air, bumi, dan matahari & & & 1 & 1 & & \\
\hline 15 & Mera wat hewan dan tumbuhan & & & 1 & 1 & & \\
\hline 16 & Keselamatan di rumah dan perjalanan & & & 1 & 1 & & \\
\hline 17 & Perkembangbiakan hewan dan tumbuhan & & & & & 1 & 1 \\
\hline 18 & Perkembangan teknologi & & & & & 1 & 1 \\
\hline 19 & Perubahan di alam & & & & & 1 & 1 \\
\hline 20 & Peduli lingkungan & & & & & 1 & 1 \\
\hline 21 & Permainan tradisional & & & & & 1 & 1 \\
\hline 22 & Indahnya Indahnya persahabatan & & & & & 1 & 1 \\
\hline 23 & Energi dan perubahannya & & & & & 1 & 1 \\
\hline
\end{tabular}


24 Bumi dan alam semesta

\section{Total}

$\begin{array}{llllll}8 & 8 & 8 & 8 & 8 & 8\end{array}$

Sumber: Buku Tematik: Buku Guru dan Buku Siswa Kelas 1-3, Edisis Revisi 2017.

Kelas rendah menjadi pilihan dalam studi ini karena tumbuhnya HOTs cenderung bersifat dinamis dan berkembang secara eksponensial sejalan dengan pengalaman dan kematangan usia (Sajidan \& Afandi, 2018). Dengan pertimbangan tersebut, upaya sadar dan terencana dalam proses pembelajaran HOTS salah satunya menyangkut ketersediaan buku ajar tematik untuk peserta didik dan desain pembelajaran dalam buku tematik untuk guru di kelas 1-3 menjadi hal yang penting sebagai dasar bagi pengembangan HOTS pada tahap perkembangan berikutnya. Proses analisis data menggunakan tiga tahapan utama, yaitu kondensasi data, penyajian data, dan penyimpulan atau verfikasi. Untuk mengecek keabsahan data, penelitian ini menggunakan triangulasi sumber(Creswell, 2009).

\section{HASIL DAN PEMBAHASAN}

Hasil penelitian ini menyajikan dua poin utama, yaitu: pertama, keterampilan berpikir tingkat tinggi yang ditumbuhkan dalam materi Buku Tematik Kelas Rendah (1-3); dan kedua, desain pebelajaran untuk menumbuhkan HOTS dalam Buku Tematik Kelas Rendah untuk kelas rendah (1-3).

\section{Keterampilan Berpikir Tingkat Tinggi yang Ditumbuhkan dalam Buku Tematik Kelas Rendah}

Berdasarkan analisis terhadap konten Buku Tematik: Buku Guru edisi revisi 2017 dari kelas 1 sampai kelas 3 jenjang SD/MI yang meliputi unsur: pemetaan kompetensi dasar, kegiatan pembelajaran, kompetensi yang dikembangkan, tujuan pembelajaran, langkah-langkah pembelajaran; ditambah analisis terhadap konten Buku Tematik: Buku Siswa edisi revisi 2017 kelas 1 sampai kelas 3 jenjang SD/MI terutama pada unsur-unsur sebagai berikut: ayo mengamati, ayo mencoba, ayo berlatih, ayo bernyanyi, dan ayo bercerita, maka dapat disajikan bahwa keterampilan berpikir tingkat tinggi yang ditumbuhkan dalam buku tematik kelas rendah meliputi 3 kategori: pertama, HOTS sebagai transfer of knowledge, kedua, HOTS sebagai berpikir kritis dan kreatif, dan ketiga, HOTS sebagai keterampilan memecahkan masalah.

\section{HOTS sebagai Transfer of Knowledge}

Penelitian ini menemukan bahwa Buku Tematik Kelas Rendah masih didominasi tujuan dan materi pembelajaran pada kategori berpikir tingkat rendah atau Low Order Thinking Skills (LOTS). Hal ini dibuktikan dari analisis dimensi pengetahuan dan dimensi proses berpikir 
menunjukkan bahwa tujuan/kompetensi dan materi yang disajikan pada Buku Tematik Kelas Rendah yang masuk pada level keterampilan berpikir tingkat tinggi atau Higher Order Thinking Skills (HOTS) sebesar 17\%. Sementara itu, sebanyak $83 \%$ tujuan/kompetensi dan materi pada Buku Tematik Kelas Rendah berada pada level keterampilan berpikir tingkat rendah (LOTS). Data selengkapnya disajikan pada Gambar 1 berikut ini.

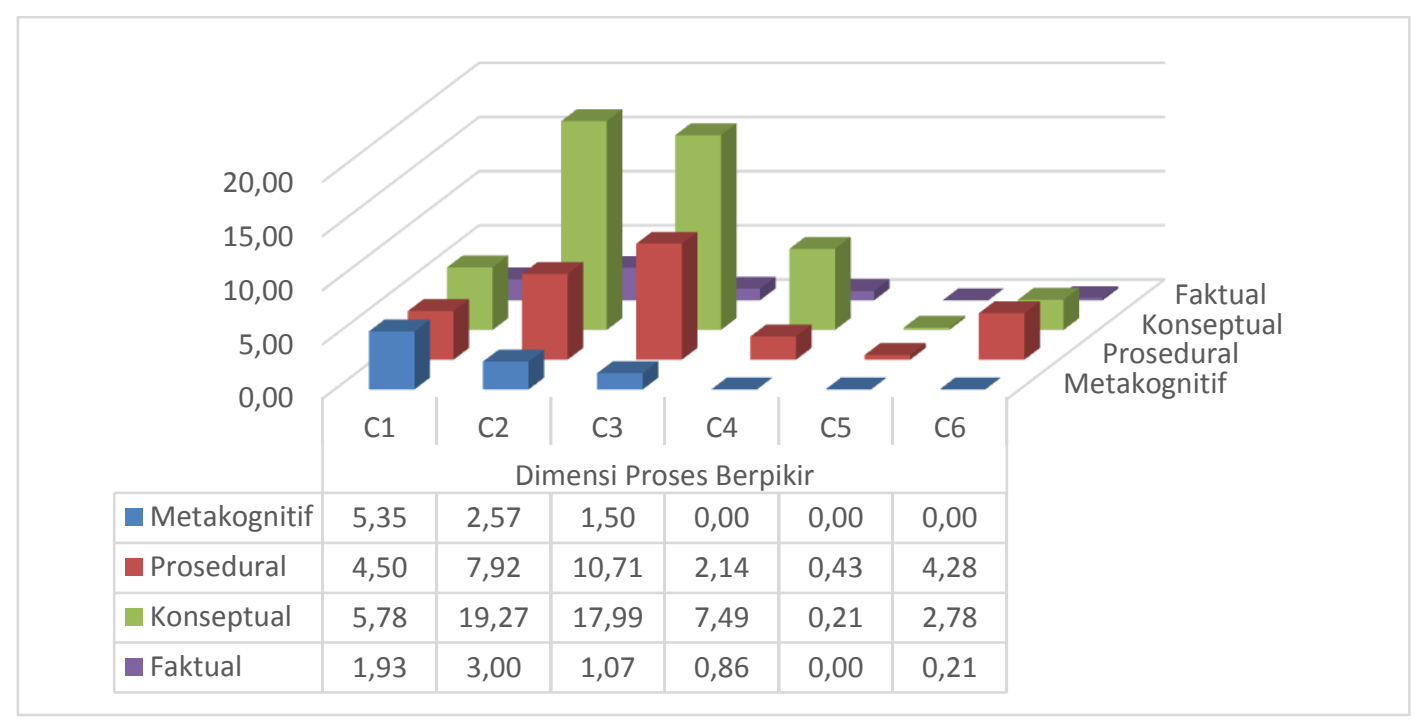

Gambar 1: Analisis Kombinasi Dimensi Pengetahuan Dan Proses Berpikir dalam Buku Tematik Kelas Rendah

Berikut ini contoh mengenai tujuan/kompetensi, kegiatan dan materi pembelajaran dalam Buku Tematik Kelas Rendah yang dapat menumbuhkan HOTS di antaranya: kegiatan pembelajaran "Berdiskusi tentang perbedaan warna anak kucing" (Sinyanyuri \& Assagaf, 2018a), "Membedakan panjang dan pendek bunyi pada lagu anak" (Astuti, 2017a), tujuan pembelajaran yaitu "Setelah membaca, siswa dapat menjelaskan perbedaan pertumbuhan dan perkembangan dengan tepat" (Sinyanyuri \& Assagaf, 2018a), materi pembelajaran "Ayo Bernyanyi” yang di dalamnya terdapat tugas yaitu: "Coba bedakan panjang pendeknya nada pada lagu berikut!" (Astuti, 2017b).

Merujuk penjelasan Ariyana, dkk, bahwa dalam matrik hubungan antara dimensi pengetahuan dan dimensi proses berpikir untuk dimensi proses berpikir C1 hingga C3 dengan seluruh dimensi pengetahuan (factual, konseptual, procedural, metakognitif) dan C1 sampai C6 dengan dimensi pengetahuan factual, masuk kategori berpikir tingkat rendah, sementara itu untuk C4 sampai C6 untuk dimensi pengetahuan konseptual, procedural, dan metakognitif adalah kategori Keterampilan Berpikir Tingkat Tinggi (Ariyana et al., 2018). Dengan demikian, data penelitian ini menunjukkan bahwa Buku Tematik Kelas Rendah masih didominasi 
tujuan/kompetensi dan materi untuk menumbuhkan LOTS, sementara tujuan/kompetensi dan materi untuk HOTS masih perlu ditingkatkan kuantitasnya.

\section{HOTS sebagai Kemampuan Berpikir Kritis dan Kreatif}

Buku Tematik Kelas Rendah juga menyajikan materi dan kegiatan pembelajaran untuk menumbuhkan keterampilan berpikir kritis. Semua subtema dari seluruh tema dalam Buku Tematik Kelas Rendah edisi revisi 2017, total berjumlah 24 tema, menyajikan materi dan kegiatan yang merangsang keterampilan berpikir kritis peserta didik. Seperti contohnya untuk kelas 1 tema 1 (Diriku) subtema 1 (Aku dan Teman Baru) pembelajaran ke-2 disajikan aktivitas yang merangsang peserta didik untuk berpikir kritis yaitu: "Amati gambar di bawah ini. Apakah yang sedang mereka lakukan? Bagaimana mereka berjalan?” (Hendrifiana, Ariguntar, \& Assagaf, 2017)

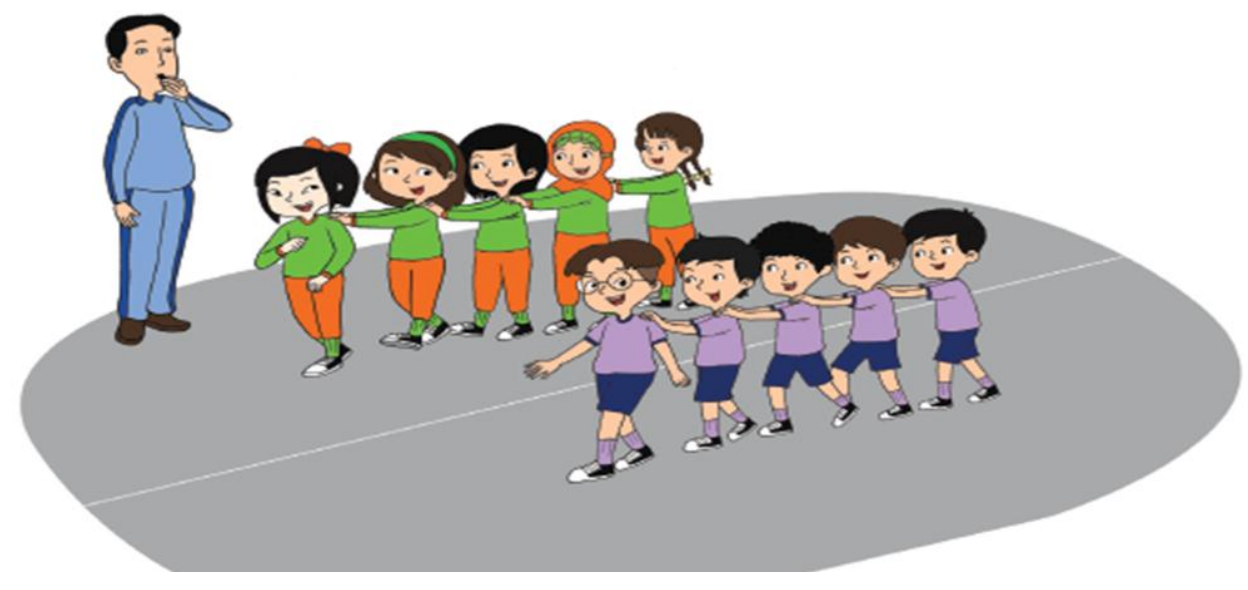

Gambar 2: Ilustrasi Bahan Pengamatan yang Melatih Berpikir Kritis Peserta didik pada Pembelajaran 2 "Bergerak Bersama Teman" Buku Tematik "Diriku"

(Hendrifiana et al., 2017)

Kemudian, aktivitas untuk merangsang keterampilan berpikir kritis peserta didik di kelas 2 yaitu contohnya terdapat pada Buku Tematik Kelas 2 tema 1 (Hidup Rukun) subtema 1 (Hidup Rukun di Rumah) pembelajaran ke-2 terdapat aktivitas Ayo Mengamati yang di dalamnya peserta didik diminta melakukan aktivitas yaitu, "Amatilah gambar di bawah ini! 
Menurut pendapatmu, pengamalan sila ke berapakah yang ditunjukkan oleh gambar ini?"(Astuti, 2017b).
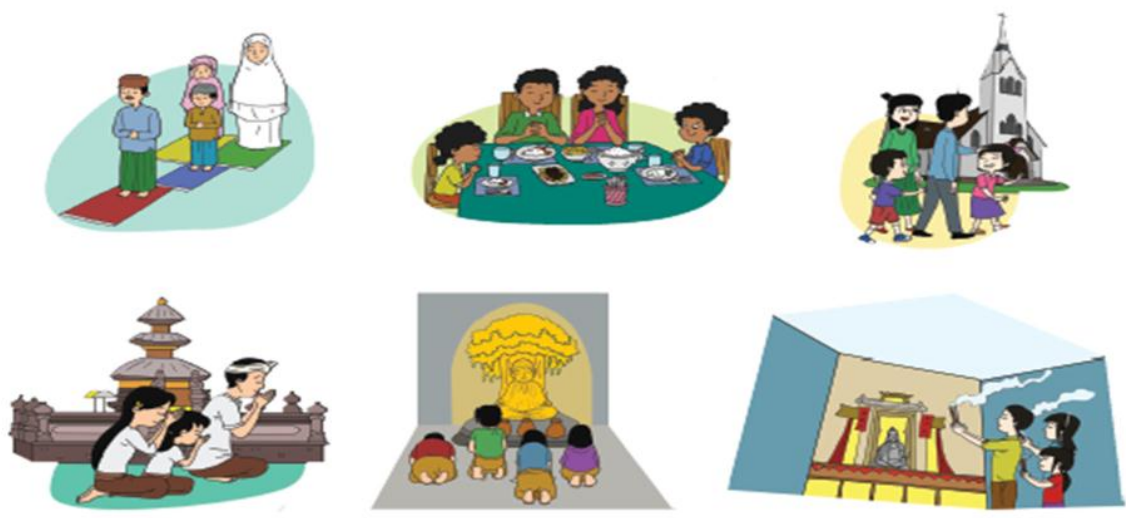

Gambar 3: Ilustrasi Bahan Pengamatan Melatih Berpikir Kritis dalam Pembelajaran 2 pada Bagian Ayo Mengamati Buku Tematik "Hidup Rukun)

(Astuti, 2017b)

Terakhir, kegiatan pembelajaran yang disajikan untuk merangsang berpikir kritis pada Buku Tematik Kelas 3 contohnya terdapat pada tema 1 (Pertumbuhan dan Perkembangan Makhluk Hidup) subtema 1 (Ciri-ciri Makhluk Hidup) pembelajaran 1 kegiatan Ayo Bernyanyi setelah semua peserta didik diminta bernyanyi bersama kemudian dilanjutkan dengan aktivitas yaitu "Bagian mana dari lagu di atas yang menunjukkan ciri-ciri makhluk hidup?" (Sinyanyuri \& Assagaf, 2018b). Berikut ini adalah lagu yang dijadikan bahan analisis tersebut.

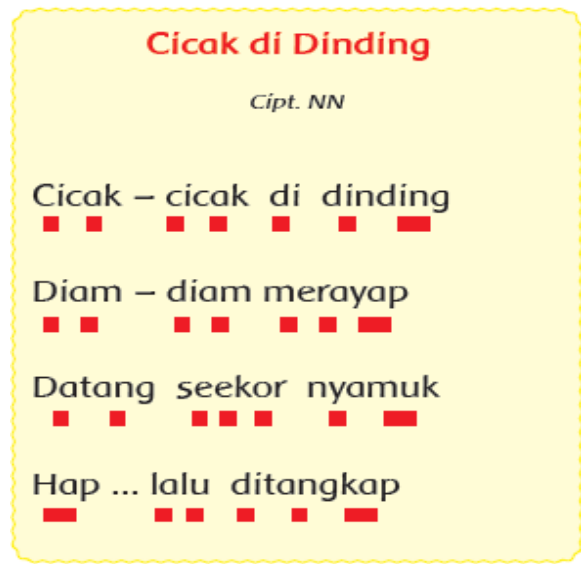

Gambar 4: : Lirik Lagu Berujudul "Cicak di Dinding” sebagai Materi untuk Menumbuhkan Berpikir Kritis Peserta Didik dalam Buku Tematik Kelas 3 Tema 1 Pembelajaran 1 (Sinyanyuri \& Assagaf, 2018b) 
Aktivitas-aktivitas yang ditunjukkan di atas sejalan dengan penjelasan Ariyana, dkk bahwa berpikir kritis adalah "proses dimana segala pengetahuan dan keterampilan dikerahkan dalam memecahkan permasalahan yang muncul, mengambil keputusan, menganalisis semua asumsi yang muncul dan melakukan investigasi atau penelitian berdasarkan data dan informasi yang telah didapat sehingga menghasilkan informasi atau simpulan yang diinginkan"(Ariyana et al., 2018). Ini berarti bahwa Buku Tematik Kelas Rendah menyajikan materi pembelajaran yang merangsang tumbuhnya keterampilan berpikir kritis pada peserta didik kelas rendah.

Selain itu, penelitian ini juga menemukan bahwa 71 persen subtema yang terdapat dalam Buku Tematik Kelas Rendah menyajikan aktivitas yang mendorong keterampilan berpikir kreatif peserta didik. Aktivitas pembelajaran yang menumbuhkan keterampilan berpikir kreatif di Buku Tematik Kelas 1 contohnya yaitu pada tema 1 (Pertumbuhan dan Perkembangan Makhluk Hidup) subtema 3 (Pertumbuhan Hewan) pembelajaran 1 terdapat aktivitas Ayo Berkreasi, yang di dalamnya menyajikan aktivitas yaitu "Perhatikan cara menggambar hias dengan motif hewan. Gambarlah hiasan dengan garis dan bidang sesuai dengan daya ciptamu! Gambarlah pada tempat yang sudah disediakan berikut!'(Sinyanyuri \& Assagaf, 2018b). Aktivitas yang merangsang keterampilan berpikir kreatif juga disajikan di kelas 2. Contohnya, Buku Tematik untuk siswa tema "Hidup Rukun" subtema 3 (Hidup Rukun di Sekolah) pembelajaran 1 dalam kegiatan Ayo Berkreasi terdapat aktivitas yaitu, "Amatilah salah satu kegiatan di sekolah. Buatlah gambar peralatan yang digunakan untuk melakukan kegiatan itu! Warnai menggunakan salah satu alat gambar" (Astuti, 2017b). Adapun contoh aktivitas yang menumbuhkan keterampilan berpikir kreatif di kelas 1 yaitu terdapat pada Buku Tematik untuk siswa tema 3 (Kegiatanku) subtema 3 (Kegiatan Sore Hari) pembelajaran 1 berupa aktivitas sebagai berikut: "Beni membuat kolase menggunakan kertas origami. Awalnya kertas origami disobek kecil-kecil. Selanjutnya, kertas origami ditempelkan pada bentuk yang sudah disiapkan. Beni membuatnya dengan hati gembira. Nah, sekarang buatlah karya kolase. Buatlah kolase bertema kegiatan sore hari” (Nurhasanah \& Assagaf, 2017).

Aktivitas-aktivitas tersebut selaras dengan pandangan Ariyani, dkk., yang mencatat bahwa "Berpikir kreatif dapat berupa pemikiran imajinatif, menghasilkan banyak kemungkinan solusi, berbeda, dan bersifat lateral'(Ariyana et al., 2018). Ini artinya, berbagai aktivitas kreatif yang disajikan melalui Buku Tematik Kelas Rendah tersebut memberikan rangsangan yang sinkron dan sesuai dengan kebutuhan berpikir kreatif, seperti imajinasi, berpikir divergen, berkemungkinan menyajikan solusi berbeda. Penjelasan tersebut juga berarti bahwa Buku Tematik Kelas Rendah memiliki kontribusi untuk pengembangan keterampilan berpikir kreatif peserta didik. 


\section{HOTS sebagai Kemampuan Memecahkan Masalah}

Buku Tematik Kelas Rendah ternyata juga menyajikan materi pembelajaran yang dapat merangsang keterampilan memecahkan masalah. Total sebarannya mencapai 50 persen dari total subtema dalam Buku Tematik Kelas Rendah menyajikan materi tersebut. Contoh dari aktivitas yang dapat menumbuhkan keterampilan memecahkan masalah bagi peserta didik kelas 1 terdapat pada tema 1 (Diriku) subtema 3 (Aku Merawat Tubuhku) pembelajaran 3 yang diawali dengan kegiatan membaca teks lagu berjudul "Gigi" kemudian dilanjutkan dengan pertanyaan yang membutuhkan solusi, yaitu "Mengapa gigi harus disikat? Diskusikan bersama temanmu"(Hendrifiana et al., 2017). Contoh aktivitas di kelas 2 dapat ditemukan di Tema 1 (Hidup Rukun) Subtema 2 (Hidup Rukun di Rumah) pembelajaran 1. Pada bagian awal pembelajaran 1, peserta didik langsung disuguhi dengan materi yang menantang kemampuan peserta didik untuk memecahkannya. Berikut pernyataan dan pertanyaannya, "Kita semua menginginkan suasana damai di rumah. Kedamaian terjadi karena adanya kerukunan. Ayah dan ibu rukun. Kakak dan adik rukun. Semua anggota keluarga menjaga kerukunan di rumah. Apa yang harus kita lakukan agar kerukunan di rumah tetap terjaga?” (Astuti, 2017b).

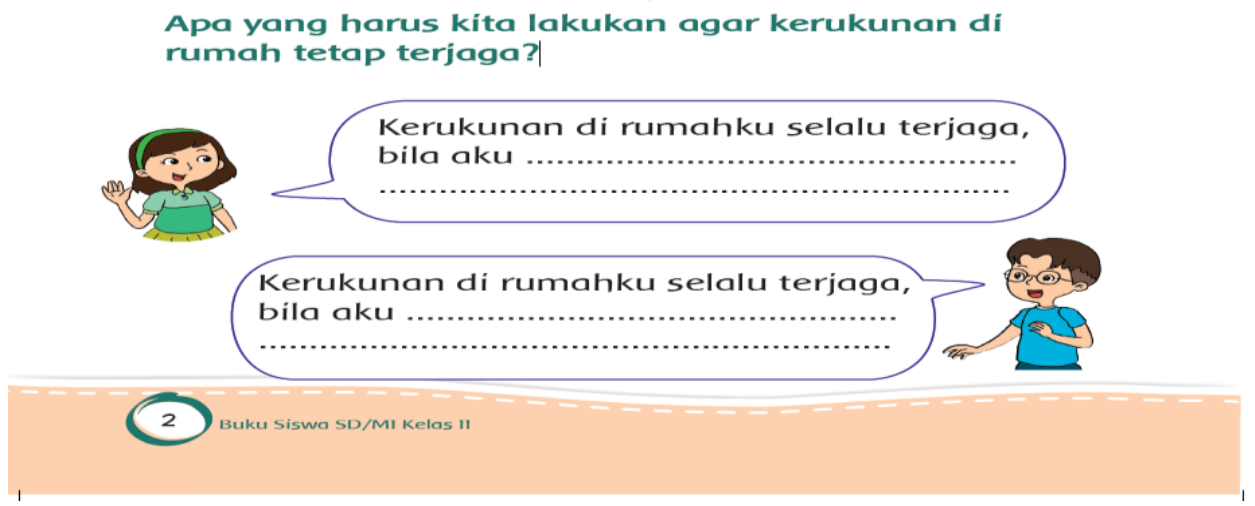

Gambar 5: Ilustrasi Pembelajaran 1 untuk Menumbuhkan Keterampilan Memecahkan Masalah pada Subtema 1 Hidup Rukun di Rumah Tema 1 Kelas 2 (Astuti, 2017b)

Buku Tematik Kelas 3 juga menyajikan aktivitas yang merangsang kemampuan memecahkan masalah. Seperti contohnya terdapat pada buku Tematik Siswa kelas 3 tema 1 (Pertumbuhan dan Perkembangan Makhluk Hidup) subtema 3 (Pertumbuhan Hewan) pembelajaran 5 teradapat bagian Ayo Berdiskusi yang menyebutkan,

"Hari ini kamu sudah belajar tentang pertumbuban kupu-kupu dan katak. Ada orang yang berani untuk menyentub kedua hewan tersebut. Ada juga orang yang tidak berani seperti pada gambar berikut ini (Gambar 6), Tuliskan saranmu agar temanmu dapat saling menghargai akan perbedaan keberanian! Tuliskan saran untuk temanmu agar lebih berani untuk memegang hewan tersebut!'(Sinyanyuri \& Assagaf, 2018b) 


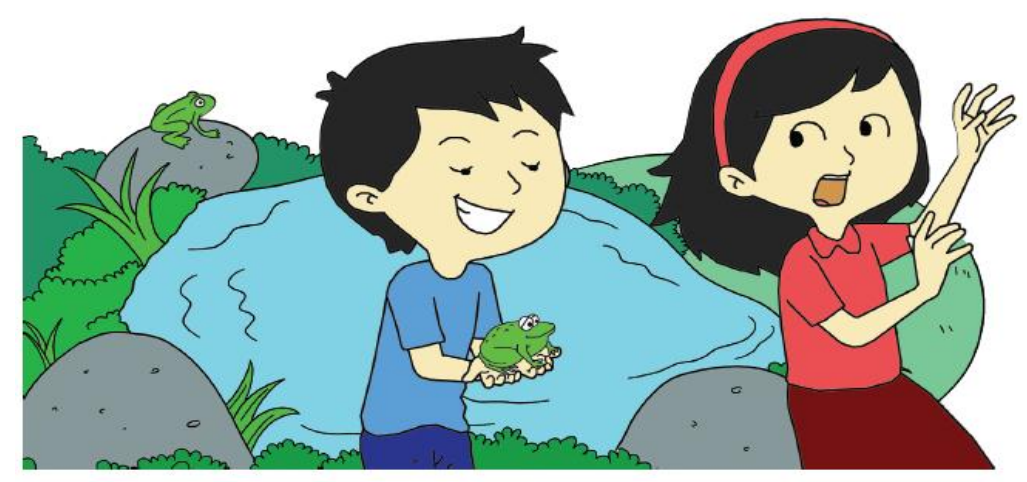

Gambar 6: Ilustrasi Bahan Diskusi yang Menumbuhkan Keterampilan Memecahkan Masalah di Buku Tematik Tema 1 Kelas 3

Berbagai aktivitas yang ditunjukkan untuk menumbuhkan keterampilan memecahkan masalah tersebut senada dengan pendapat Ariyani, dkk, yang mengatakan, "Keterampilan pemecahan masalah merupakan keterampilan para ahli yang memiliki keinginan kuat untuk dapat memecahkan masalah yang muncul pada kehidupan sehari- hari” (Ariyana et al., 2018). Penjelasan ini juga menegaskan bahwa Buku Tematik Kelas Rendah juga dapat berkontribusi untuk menumbuhkan kemampuan memecahkan masalah. Kemampuan memecahkan masalah merupakan bagian yang tidak terpisahkan dari keterampilan berpikir tingkat tinggi (HOTS).

Temuan penelitian ini yang mengungkapkan bahwa Buku Tematik Kelas Rendah pada jenjang Sekolah Dasar/ Madrasah Ibtidaiyah memiliki kontribusi untuk menumbuhkan keterampilan berpikir tingkat tinggi bagi peserta didik. Kontribusi tersebut ditegaskan dengan keberadaan tujuan/kompetensi, materi dan kegiatan pembelajaran yang disajikan dalam buku tematik tersebut selaras dengan kebutuhan pengembangan keterampilan berpikir tingkat tinggi. Penelitian ini menemukan bahwa Buku Tematik Kelas Rendah mampu menumbuhkan HOTS pada tiga kategori: pertama, HOTS sebagai transfer of knowledge. Pada kategori pertama ini, Buku Tematik Kelas Rendah di SD/MI hanya mampu menyajikakan sebagian kecil materi yang dibutuhkan untuk pengembangan HOTS, sedangkan sebagian besar masih didominasi untuk LOTS. Kedua, HOTS sebagai keterampilan berpikir kritis dan kreatif. Kegiatan pembelajaran yang disajikan dalam Buku Tematik Kelas Rendah sebagian besar telah mendukung pembelajaran yang mendorong kemampuan berpikir kritis $(100 \%)$ dan kreatif (70\%). Ketiga, HOTS sebagai keterampilan memecahkan masalah. Meskipun belum mendominasi seluruh tema dan subtema yang disajikan pada Buku Tematik Kelas Rendah, namun setidaak-tidaknya separuh dari seluruh subtema yang disediakan telah menyediakan aktivitas yang merangsang peserta didik untuk menguasai keterampilan memcahkan masalah. Temuan ini mengungkapkan pula bahwa tujuan / kompetesi dan materi yang disajikan dalam Buku Tematik Kelas Rendah 
sebaiknya perlu disinkronkan kembali dengan aktivitas pembelajaran yang merangsang tumbuhnya keterampilan berpikir tingkat tinggi. Dengan demikian, harapan awal bahwa perubahan model pembelajaran dari berbasis mata pelajaran menjadi berbasis tema yang diarahkan agar pembelajaran lebih menumbuhkan keterampilan berpikir tingkat tinggi dapat direalisasikan.

\section{Desain Pembelajaran untuk Menumbuhkan Keterampilan Berpikir Dalam Buku Tematik Kelas Rendah}

Buku Tematik yang digunakan di jenjang SD/MI terdiri dari dua jenis, yaitu buku guru dan buku siswa. Buku guru adalah buku yang menjadi pegangan dan acuan sekaligus pertimbangan perencanaan, pelaksanaan, dan penilaian pembelajaran bagi guru. Buku siswa adalah buku yang menjadi salah satu sumber belajar dan bahan ajar bagi peserta didik. Buku siswa berisi penjelasan global tentang isi dan penggunaan buku, daftar isi, materi ajar, dan daftar pustaka. Buku siswa menjadi pegangan bagi peserta didik dalam proses pembelajaran. Materi dan aktivitas yang akan dipelajari sekaligus dilaksanakan selama proses pembelajaran dapat dipelajari oleh peserta didik melalui buku tersebut.

Penelitian ini menemukan berbagai pendekatan, model, strategi, dan metode pembelajaran yang disajikan dalam buku guru untuk Buku Tematik Kelas Rendah. Gambar 7 menyajikan peta seluruh pendekatan, model, strategi, dan metode pembelajaran yang terdapat pada buku guru Buku Tematik Kelas Rendah (Kelas 1-3). 


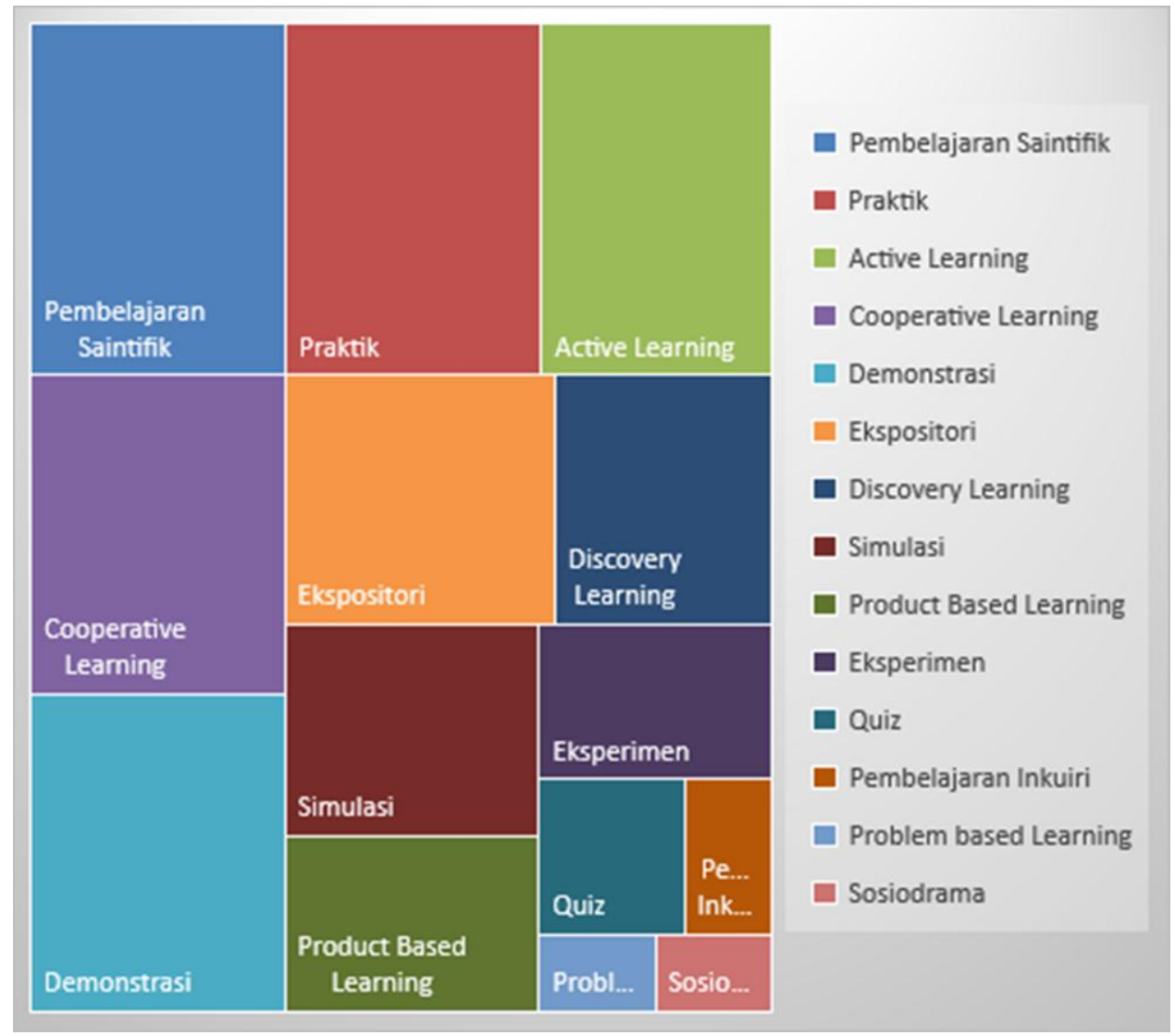

Gambar 7: Peta Pendekatan, Model, Strategi, dan Metode Pembelajaran pada buku guru Buku Tematik Kelas Rendah

Penjelasan Gambar 7 di atas yaitu pendekatan pembelajaran saintifik dan metode praktik selalu digunakan pada setiap subtema dalam Buku Tematik Kelas Rendah jenjang SD/MI dengan berbagai variannya. Model cooperative learning, strategi active learning, dan metode demonstrasi hampir (90\%) selalu ada di setiap subtema. Model discovery learning, model ekspositori dan metode simulasi digunakan pada mayoritas subtema yang disajikan pada Buku Tematik Kelas Rendah. Sementara itu, model pembelajaran berbasis produk digunakan pada separuh subtema yang disajikan. Metode eksperimen dan quiz dipakai kurang dari separuh dari total subtema yang disediakan. Sedangkan model pembelajaran inkuiri, model pembelajarana berbasis masalah, dan metode sosiodrama hanya digunakan pada sebagian kecil dari subtema yang disajikan.

Berdasarkan paparan hasil penelitian di atas terlihat bahwa pendekatan saintifik, strategi active learning, praktik, demonstrasi, dan cooperative learning telah menjadi pilihan utama di 
semua subtema. Ini juga menunjukkan perubahan kurikulum, dari Kurikulum 2006 ke Kurikulum 2013 telah berdampak nyata pada transformasi paradigma desain pembelajaran di jenjang SD/MI dalam buku guru Buku Tematik kelas rendah yaitu dari teacher centered ke arah student centered. Mayoritas pendekatan, model, strategi, dan metode pembelajaran dari total 14 jenis yang digunakan dalam buku guru Buku Tematik Kelas Rendah mengarahkan peserta didik untuk berpikir secara aktif, bukan sekedar mekanistik. Berbagai jenis pendekatan, model, strategi, dan metode pembelajaran tersebut mayoritas juga memiliki keselarasan dengan kebutuhan peningkatan keterampilan berpikir tingkat tinggi.

Penjelasana di atas senada dengan pandangan Ariyani, dkk, yang menyatakan bahwa model Pembelajaran Melalui Penyingkapan/Penemuan (Discovery/Inquiry Learning), model Pembelajaran Berbasis Masalah (Problem-based Learning/PBL), (3) model Pembelajaran Berbasis Projek (Project- based Learning/PJBL), dan Cooperative Learning dapat menumbuhkan perilaku saintifik, sosial serta mengembangkan rasa keingintahuan yang selaras dan tidak terpisahkan dengan keterampilan berpikir tingkat tinggi (Ariyana et al., 2018). Sebagian besar desain pembelajaran yang disajikan dalam buku guru Buku Tematik kelas rendah tersebut sejalan dengan aktivitas peserta didik dalam pembelajaran menumbuhkan HOTS, yaitu: aktif dalam berpikir, memformulasikan masalah, mengkaji permasalahan yang kompleks, berpikir divergen dan mengembangkan ide, mencari informasi dari berbagai sumber, berpikir kritis dan menyelesaikan masalah secara kreatif, berpikir analitik, evaluative, dan membuat keputusan (Sani, 2019).

Meskipun demikian, masih kecilnya penggunaan pembelajaran inkuiri dan pembelajaran berbasis masalah menjadi tantangan tersendiri bagi pengembangan HOTS peserta didik. Oleh karena, pembelajaran inkuiri adalah model yang cocok digunakan untuk mengasah keterampilan HOTS, utamanya adalah yang bersifat open ended (terbuka) dan berbasis problem solving (pemecahan masalah). Guru dalam inkuiri terbuka berfungsi sebagai fasilitator. Lantas, peserta didik dapat mengajukan pertanyaan yang mendasar dari suatu permasalahan dan peserta didik juga menemukan sendiri jawabannya melalui penalaran yang benar. Dari proses inilah peserta didik dilatih berpikir secara kompleks dan networking (Nugroho, 2018).

\section{SIMPULAN}

Keberadaan buku tematik yang muncul seiring sejalan dengan penerapan model pembelajaran tematik di jenjang SD/MI memiliki konten yang sejalan dengan upaya menumbuhkan keterampilan berpikir tingkat tinggi. Buku tematik kelas rendah terbukti memiliki sejumlah konten, baik dari segi tujuan/kompetensi, kegiatan, maupun materi pembelajaran yang sejalan dengan karakteristik HOTS. Meskipun demikian, kuantitas konten yang sejalan dengan HOTS terutama dalam kategori transfer of knowledge masih banyak yang perlu disinkronkan kembali. Adapun konten yang menyajikan aktivitas yang merangsang 
keterampilan berpikir kritis dan kreatif, sekaligus problem solving sudah semakin memadai. Terakkhir, desain pembelajaran yang disajikan dalam Buku Tematik kelas rendah, khususnya pada buku guru, mayoritas telah menyajikan dan menggunakan pendekatan, model, strategi, dan metode pembelajaran yang mengarah kepada pendekatan saintifik, pendekatan berpusat pada peserta didik dan strategi pembelajaran aktif yang sejalan dengan karakteristik HOTS.

Meskipun demikian, efektivitas dari Buku Tematik kelas rendah ini masih perlu dilakukan uji dan mungkin dilakukan riset lanjutan untuk menguji efektivitasnya dalam menumbuhkan HOTS pada peserta didik di jenjang SD/MI. Di samping itu, penelitian ini perlu pula ditindaklanjuti dengan studi berikutnya yang berfokus pada implementasi dari pemanfaatan Buku Tematik tersebut di lapangan dengan berbagai dinamikanya. Karena kadang terjadi, desain yang baik bisa lain kejadinnya ketika sudah diterapkan di lapangan.

\section{DAFTAR PUSTAKA}

Anwar, R. (2014). HAL-HAL YANG MENDASARI PENERAPAN KURIKULUM 2013. Humaniora, 5(1), 97-106. Retrieved from https://journal.binus.ac.id/index.php/Humaniora/article/view/2987/2378

Ardiansyah, M. Z. (2018). Higher-Order Thinking Skills: Strategi Kontra Radikalisme Santri Pesantren. Ibriez: Jurnal Kependidikan Dasar Islam Berbasis Sains, 3(2), 121-132. https://doi.org/10.21154/IBRIEZ.V3I2.51

Ariyana, Y., Pudjiastuti, A., \& Bestary, R. (2018). Buku Pegangan Pembelajaran Berorientasi pada Keterampilan Berpikir Tingkat Tinggi: Program Peningkatan Kompetensi Pembelajaran Berbasis Zonasi. 95.

Astuti, I. M. J. (2017a). Hidup Rukun: Buku Guru. Jakarta: Kementerian Pendidikan dan Kebudayaan.

Astuti, I. M. J. (2017b). Hidup Rukun. Jakarta: Kementerian Pendidikan dan Kebudayaan.

Creswell, J. W. (2009). Research Design: Qualitative, Quantitative, and Mixed Methods Approaches. Third Edition. London: SAGE Publications.

Hamdu, G., Lestari, A., \& Nurlaila, N. (2016). IMPLEMENTASI PERANGKAT PEMBELAJARAN BERBASIS MASALAH PADA SISWA KELAS V SEKOLAH DASAR. Jurnal Penelitian Pendidikan, 16(3), 244-250. Retrieved from http://ipa.unnes.ac.id/wp-content/uploads/2018/04/Artikel-Prof.-Sajidan-SemnasIPA-2018.pdf

Hendrifiana, Y., Ariguntar, P., \& Assagaf, L. (2017). Diriku. Jakarta: Kementerian Pendidikan dan Kebudayaan.

Mullis, I. V. S., Martin, M. O., \& Loveless, T. (2016). 20 Years of TIMSS International Trends 
in Mathematics and Science Achievement, Curriculum, and Instruction. In Chestnut Hill: TIMSS \& PIRLS International Study Center Lynch School of Education Boston College. Massachusetts: TIMSS \& PIRLS International Study Center, Lynch School of Education, Boston College and International Association for the Evaluation of Educational Achievement (IEA).

Nugroho, R. A. (2018). HOTS (Kemampuan Berpikir Tingkat Tinggi: KOnsep, Pembelajaran, Penilaian, dan Soal-Soal). Jakarta: Gramedia Widiasarana Indonesia.

Nurhasanah, \& Assagaf, L. (2017). Kegiatanku. Jakarta: Kementerian Pendidikan dan Kebudayaan.

OECD. (2018). PISA 2015. Retrieved from https://www.oecd.org/pisa/pisa-2015-results-infocus.pdf

OECD Indonesia. (2016). INDONESLA AKTIF BERSAMA. Retrieved from http://www.oecd.org/global-relations/Active_with_Indonesia_BA.pdf

Pratiwi, P. H., Hidayah, N., \& Martiana, A. (2017). PENGEMBANGAN MODUL MATA KULIAH PENILAIAN PEMBELAJARAN SOSIOLOGI BERORIENTASI HOTS (HIGHER ORDER THINKING SKILLS). Jurnal Cakrawala Pendidikan, 36(2). https://doi.org/10.21831/cp.v36i2.13123

Sahoo, S., \& Mohammed, C. A. (2018). Fostering critical thinking and collaborative learning skills among medical students through a research protocol writing activity in the curriculum. J Med Educ, 30(2), 109-118. https://doi.org/10.3946/kjme.2018.86

Sajidan, \& Afandi. (2018). Pemberdayaan keterampilan beripikir tingkat tinggi ditinjau dari aspek epigenetik dan implikasinya dalam pendidikan. (April). https:/ / doi.org/10.13140/RG.2.2.14608.05129

Sani, R. A. (2019). Pembelajaran Berbasis HOTS (Higher Order Thinking Skills). Jakarta: Tira Smart. Sendari, A. A. (2019). Tujuan Kurikulum 2013 di Balik Pro Kontra Penerapannya. Retrieved from Liputan6.Com website: https:/ /www.liputan6.com/citizen6/read/3875318/tujuan-kurikulum-2013-di-balikpro-kontrapenerapannya?related=dable\&utm_expid=.9Z4i5ypGQeGiS7w9arwTvQ.1\&utm_referre $\mathrm{r}=\mathrm{https} \% 3 \mathrm{~A} \% 2 \mathrm{~F} \% 2 \mathrm{Fwww} \cdot g o 0 g$ le.com $\% 2 \mathrm{~F}$

Sinyanyuri, S., \& Assagaf, L. (2018a). Pertumbuban dan Perkembangan Makbluk Hidup: Buku Guru. Jakarta: Kementerian Pendidikan dan Kebudayaan.

Sinyanyuri, S., \& Assagaf, L. (2018b). Pertumbuban dan Perkembangan Makhluk Hidup. Jakarta: Kementerian Pendidikan dan Kebudayaan.

Tajudin, N. M., \& Chinnappan, M. (2016). The Link between Higher Order Thinking Skills, 
Representation and Concepts in Enhancing TIMSS Tasks. International Journal, 9(2). https://doi.org/10.12973/iji.2016.9214a

Tim Redaktur Bernas. (2017). Peringkat Berapakah Indonesia di TIMSS? Retrieved from Bernas.Id website: https://www.bernas.id/50899-peringkat-berapakah-indonesia-ditimss.html

TIMSS. (2015). East Asian Countries Top Achievers at Fourth Grade in Mathematics International Mathematics Achievement The gap between the East Asian countries and the next highest country was. Retrieved from http://timss2015.org/download-center/

Tjalla, A. (2010). Potret Mutu Pendidikan Indonesia Ditinjau dari Hasil-hasil Studi Internasional. Retrieved from http://www.webometrics.info/top100_continent.asp?cont=asia

Wahid, A. H., \& Karimah, A. R. (2018). INTEGRASI HIGHER ORDER THINKING SKILL(HOTS) DENGAN MODELCREATIVE PROBLEMSOLVING. MODELING: Jurnal Program Studi PGMI, 5(1), 82-98. Retrieved from http://jurnal.stitnualhikmah.ac.id/index.php/modeling/article/view/161/143

Yuliati, L. (2013). EFEKTIVITAS BAHAN AJAR IPA TERPADU TERHADAP KEMAMPUAN BERPIKIR TINGKAT TINGGI SISWA SMP. Jurnal Pendidikan Fisika Indonesia, 9(1). https://doi.org/10.15294/jpfi.v9i1.2580

Yuriza, P. E., Adisyahputra, A., \& Sigit, D. V. (2018). Correlation between higher-order thinking skills and level of intelligence with scientific literacy on junior high school students. Biosfer, 11(1), 13-21. https://doi.org/10.21009/biosferjpb.11-1.2 